\title{
Meat Consumption and Cancer Risk
}

\author{
Jeanine M. Genkinger ${ }^{\circledR}$, Anita Koushik ${ }^{\circledR *}$
}

$\mathrm{T}$ he large international variation in incidence rates of cancer, together with findings from migrant studies, suggest that environmental factors such as diet are associated with cancer risk. The intake of meats, such as beef, varies 3-fold across the world-consumption is highest in developed countries (23 $\mathrm{kg}$ /capita) compared to less developed countries (6 kg/capita) [1]. Based on Richard Doll and Richard Peto's work in 1981, it has been estimated that approximately $35 \%$ (range $10 \%-70 \%$ ) of cancer can be attributed to diet, similar in magnitude to the contribution of smoking to cancer (30\%, range $25 \%-40 \%$ ) [2].

Meat consumption in relation to cancer risk has been reported in over a hundred epidemiological studies from many countries with diverse diets. The association between meat intake and cancer risk has been evaluated by looking both at broad groupings of total meat intake, and also at finer categorizations, particularly intakes of red meat, which includes beef, lamb, pork, and veal, and also more specifically processed meats, which includes meats preserved by salting, smoking, or curing.

Although the association of cancer and meat intake may be partially explained by high-energy or high-fat ("westernized") diets, of greater interest is a possible direct role of potentially carcinogenic compounds that are found in meats, including N-nitroso compounds, heterocyclic amines, or polycyclic aromatic hydrocarbons. Nnitroso compounds are broad-acting potent carcinogens in animal models [3] and include nitrosamines, which require metabolic activation to be converted to a carcinogenic form, and nitrosamides, which do not require activation. Similarly, heterocyclic amines are classified as mutagens

Research in Translation discusses health interventions in the context of translation from basic to clinical research, or from clinical evidence to practice.

\section{Linked Research Article}

This Research in Translation article discusses the following new study published in PLoS Medicine:

Cross AJ, Leitzmann MF, Gail MH, Hollenbeck AR, Schatzkin A, et al. (2007) A prospective study of red and processed meat intake in relation to cancer risk. PLoS Med 4(12): e325. doi:10.1371/ journal.pmed.0040325

Using data from a large cohort study, Amanda Cross and colleagues found that both red and processed meat intakes were positively associated with cancers of the colorectum and lung.

and animal carcinogens [4-8]. These compounds and others present in meats (salts, nitrates, nitrites, heme iron, saturated fat, estradiol) have been theorized to increase DNA synthesis and cell proliferation, increase insulinlike growth factors, affect hormone metabolism, promote free radical damage, and produce carcinogenic heterocyclic amines [9-16], all of which may promote the development of cancer.

\section{Colorectal Cancer}

The malignancy most extensively studied in relation to meat intake has been colorectal cancer. In ecological studies, correlations between international per capita meat intakes and colon cancer incidence $(r>0.85)$ and mortality $(r>0.70)$ rates have been high $[17,18]$. Similarly, raised colorectal cancer risks in relation to both red and processed meat intakes have been observed in case-control and cohort studies. A 1997 review of these studies, sponsored by the World Cancer Research Fund and the American Institute for Cancer Research, concluded that the intake of red meat probably increases the risk of colorectal cancer, while processed meat possibly increases colorectal cancer risk [19]. A similar consensus was reported by the Colon Cancer Panel at the World Health Organization consensus conference [20] and the
Working Group on Diet and Cancer of the Committee on Medical Aspects of Food and Nutrition Policy [21]. In recent meta-analyses of colorectal cancer that included studies published up to 2005 [22-24], summary associations indicated that red meat intakes were associated with $28 \%-35 \%$ increased risks while processed meats were associated with elevated risks of $20 \%-49 \%$.

\section{Other Types of Cancer}

Additionally, a large number of studies have examined the association between meat intake and stomach cancer risk. In a recent meta-analysis, positive associations were observed between processed meat consumption and stomach cancer risk, although the results from case-control versus cohort studies were heterogeneous [25]. Fewer studies with less consistent associations have been reported for cancers of the bladder [26,27], breast $[28,29]$, endometrium [30], glioma

Funding: The authors received no specific funding for this article.

Competing Interests: The authors have declared that no competing interests exist.

Citation: Genkinger JM, Koushik A (2007) Meat consumption and cancer risk. PLoS Med 4(12): e345. doi:10.1371/journal.pmed.0040345

Copyright: $\odot 2007$ Genkinger and Koushik. This is an open-access article distributed under the terms of the Creative Commons Attribution License, which permits unrestricted use, distribution, and reproduction in any medium, provided the original author and source are credited.

Abbreviations: AARP, formerly known as the American Association of Retired Persons; FFQ, food frequency questionnaire; $\mathrm{NIH}$, National Institutes of Health

Jeanine M. Genkinger is at the Department of Oncology, Division of Cancer Genetics and Epidemiology, Lombardi Comprehensive Cancer Center, Georgetown University, Washington,

D. C. United States of America. Anita Koushik is at the Département de médecine sociale et préventive, Université de Montréal, and Axe Santé des populations, Centre de recherche du CHUM, Montreal, Quebec, Canada.

*To whom correspondence should be addressed. E-mail: anita.koushik@umontreal.ca

- These authors contributed equally to this work. 
[31], pancreas [32-34], prostate [35], and renal cell [36]. There has been even less research on the association between meat intake and cancers of the lung [37,38], esophagus [39], oral cavity [40,41], ovary [42-44], cervix [45], and liver [41]. Most of the studies examining these sites have been casecontrol, and some of the earlier studies lacked adjustment for energy intake or body mass index, two key potential confounders.

\section{A New Study of Multiple Cancer Sites}

In this issue of PLoS Medicine, Amanda Cross and colleagues present their findings from a large prospective cohort study on the association between red and processed meat intake and cancer at several sites [46]. Their analysis is based on the prospective National Institutes of Health (NIH)-AARP (formerly known as the American Association of Retired Persons) Diet and Health Study and includes almost 500,000 men and women in the United States, among whom over 53,000 incident cancers occurred.

For colorectal cancer, a 24\% increased risk with red meat consumption of $62.5 \mathrm{~g} / 1,000 \mathrm{kcal}$ and a $20 \%$ increased risk with processed meat consumption of $22.6 \mathrm{~g} / 1,000 \mathrm{kcal}$ was observed among both men and women, which is similar in magnitude to the summary relative risks observed in previous meta-analyses [22-24]. The researchers also found that increasing intakes of red meat were significantly associated with elevated risks of $20 \%-$ $60 \%$ for cancers of the esophagus, liver, and lung. For processed meats, a $16 \%$ increased risk of lung cancer was observed. Red and processed meat intake was associated with an increased pancreatic cancer risk in men only.

The results from the NIH-AARP Diet and Health Study corroborate previous findings for colorectal cancer. However, a positive association with stomach cancer, which has been seen mostly in previous case-control investigations, was not observed in the NIH-AARP Diet and Health Study. Relative risks for stomach cancer have been primarily null in previous cohort studies compared to case-control studies, and thus the NIH-AARP Diet and Health Study results for stomach cancer are consistent with previous cohort studies.

Five Key Papers in the Field

Larsson et al, 2006 [22] A meta-analysis of epidemiological studies of meat and colorectal cancer that used a prospective design, which is less susceptible to recall and selection biases.

Larsson et al., 2006 [25] A thorough qualitative and quantitative review of case-control and cohort studies on stomach cancer, with a focus on intake of processed meat, which may contain higher levels of carcinogenic compounds compared to other meats.

Missmer et al., 2002 [28] In this study, meat intake and breast cancer risk were examined by pooling the original primary data from eight prospective cohort studies, allowing for the analysis of various exposures and population subgroups.
A pooled analysis is less susceptible to publication bias compared to metaanalyses of the published literature.

Sinha R (2002) An epidemiologic approach to studying heterocyclic amines. Mutat Res 506-507: 197-204. This article describes the development of a database to estimate intakes of heterocyclic amines, a potentially important contributor to the association between meat and cancer risk, from food frequency questionnaire data.

Sinha R, Norat T (2002) Meat cooking and cancer risk. IARC Sci Publ 156: 181-186. A general overview of the association between meat and cancer risk, with a special emphasis on cooking techniques.
In Cross and colleagues' study, higher consumption of meat was positively associated with risk of cancer of the lung, liver, esophagus, and pancreas, similar to the findings from some [32,37-40,47-52] but not all [33,41,53-58], previous casecontrol and cohort studies. An inverse association with endometrial cancer was observed in the NIH-AARP Diet and Health Study, which is in contrast to the positive association reported in the recent meta-analysis by Elisa Bandera et al. [30]. This meta-analysis was based on 16 case-control studies, among which recall and selection biases cannot be ruled out.

\section{Strengths and Weaknesses of the New Study}

The NIH-AARP investigation is based on high-quality prospective dietary information obtained using a validated food frequency questionnaire (FFQ) with 124 items [59]. The analyses were conducted using only baseline FFQ data covering recent intakes; thus, changes in intakes of meat and other nutrients over time, as well as lifetime consumption patterns, could not be evaluated in the NIH-AARP study. Additionally, because the NIHAARP study measured adult red and processed meat intake, it may not have captured the relevant exposure time for carcinogenesis, which may have occurred in childhood, adolescence, or early adulthood.

Nonetheless, in this study, diet was measured prior to diagnosis of cancer; thus, a cancer diagnosis would not have influenced the reporting of meat intake, minimizing the potential for recall bias. Additionally, the potential for selection bias was minimized as the cohort follow-up rate was very high (more than 95\%). Furthermore, the NIH-AARP investigation is based on high-quality prospective measurement of other important environmental factors (e.g., smoking, body mass index), a long follow-up time (8.2 years), and a large number of cases of cancer. Because of the large population size, the NIH-AARP Diet and Health Study was able to prospectively analyze several rare cancer sites, including brain, laryngeal, non-Hodgkin lymphoma, pancreatic, pharyngeal, renal, and thyroid. The great variation in red and processed meat intake among the NIH-AARP population allowed for the examination of these specific cancer sites to be conducted with relatively sufficient power, thus greatly adding to the dearth of prospective literature to date on these rare cancers.

In interpreting the findings from studies of meat intake and cancer, it should be noted that individuals who consume a diet high in red and processed meat typically also consume large amounts of foods such as butter, potatoes, refined grains, and high-fat dairy, all components of a westernized diet [60]. Thus red and processed meat intake might not be solely responsible for higher cancer risk. Additionally, meat intake is usually correlated with 
higher energy intakes [61,62] and obesity [63], so residual confounding may be present. Research aimed at understanding how foods and nutrients interact to promote or prevent carcinogenesis may provide a better understanding of potential etiological pathways and may explain some of the heterogeneity of published results.

\section{Next Steps in Research}

Further knowledge would be gained from research examining differences in particular subtypes of specific cancers. For example, different histologies or cancer subsites, such as estrogen-receptor-negative breast cancers or cardia gastric cancers, may be more strongly associated with dietary risk or preventive factors. Similarly, risk variation according to specific genotypes at polymorphic sites, for instance in genes involved in the metabolism of carcinogenic compounds in meat, may add further to our understanding of the role of meat consumption in cancer risk.

In addition to investigating intakes of food items or groups (i.e., red or processed meat), future research should also examine particular nutrients within meats (e.g., iron) or carcinogenic components (e.g., heterocyclic amines, nitrosamines) that are created as a result of certain cooking techniques, particularly among the rarer and less studied cancers. Other factors, such as animal raising and feeding practices (exogenous sex steroids are used in farm-raised animals in the US and banned in the farming industry in the European Union), may also contribute to cancer risk $[64,65]$. Few studies have examined these practices in their analyses, which may explain some of the inconsistency in results across studies.

\section{Conclusion}

In summary, red and processed meat intake appears to be positively associated with risk of cancer of the colon and rectum, esophagus, liver, lung, and pancreas in a new, large US cohort study of 500,000 men and women. However, this study provided little support for an association with other cancer sites. Current dietary guidelines recommend selecting meats that are lean, low-fat, or fat-free [66], thus promoting limited consumption of red and processed meats. Overall, the strongest risk factors for cancer in the US are smoking and obesity [67]. However, understanding the complex interaction of diet with smoking and obesity, and how specific foods and nutrients are metabolized, may provide further clues into the etiology and, most importantly, the prevention of cancer.

\section{References}

1. Delgado CL (2003) Rising consumption of meat and milk in developing countries has created a new food revolution. J Nutr 133: 3907S-3910S.

2. Doll R, Peto R (1981) The causes of cancer: quantitative estimates of avoidable risks of cancer in the United States today. J Natl Cancer Inst 66: 1191-1308.

3. Lijinsky W (1999) N-nitroso compounds in the diet. Mutat Res 443: 129-138.

4. Ohgaki H, Hasegawa H, Kato T, Suenaga M, Sato S, et al. (1985) Carcinogenicities in mice and rats of IQ, MeIQ and MeIQx. Princess Takamatsu Symp 16: 97-105.

5. Ito N, Hasegawa R, Sano M, Tamano S, Esumi $\mathrm{H}$, et al. (1991) A new colon and mammary carcinogen in cooked food, 2-amino-1-methyl6-phenylimidazo[4,5-b]pyridine (PhIP). Carcinogenesis 12: 1503-1506.

6. Ito N, Hasegawa R, Shirai T, Fukushima S, Hakoi K, et al. (1991) Enhancement of GST-P positive liver cell foci development by combined treatment of rats with five heterocyclic amines at low doses. Carcinogenesis 12: 767-772.

7. Ghoshal A, Preisegger KH, Takayama S, Thorgeirsson SS, Snyderwine EG (1994) Induction of mammary tumors in female Sprague-Dawley rats by the foodderived carcinogen 2-amino-1-methyl-6phenylimidazo[4,5-b]pyridine and effect of dietary fat. Carcinogenesis 15: 2429-2433.

8. Weisburger JH, Rivenson A, Reinhardt J, Aliaga C, Braley J, et al. (1994) Genotoxicity and carcinogenicity in rats and mice of 2-amino-3,6dihydro-3-methyl-7H-imidazolo[4,5-f] quinolin7- one: an intestinal bacterial metabolite of 2-amino-3-methyl-3H-imidazo[4,5-f] quinoline. J Natl Cancer Inst 86: 25-30.

9. Norrish AE, Ferguson LR, Knize MG, Felton JS, Sharpe SJ, et al. (1999) Heterocyclic amine content of cooked meat and risk of prostate cancer. J Natl Cancer Inst 91: 2038-2044.

10. Gann PH, Hennekens CH, Sacks FM, Grodstein F, Giovannucci EL, et al. (1994) Prospective study of plasma fatty acids and risk of prostate cancer. J Natl Cancer Inst 86: 281-286.

11. Allen NE, Appleby PN, Davey GK, Key TJ (2000) Hormones and diet: low insulin-like growth factor-I but normal bioavailable androgens in vegan men. Br J Cancer 83: 95-97.

12. Habito RC, Montalto J, Leslie E, Ball MJ (2000) Effects of replacing meat with soyabean in the diet on sex hormone concentrations in healthy adult males. Br J Nutr 84: 557-563.

13. Ngo TH, Barnard RJ, Cohen P, Freedland S, Tran C, et al. (2003) Effect of isocaloric low-fat diet on human LAPC-4 prostate cancer xenografts in severe combined immunodeficient mice and the insulin-like growth factor axis. Clin Cancer Res 9: 2734 2743

14. Weinberg ED (1996) The role of iron in cancer. Eur J Cancer Prev 5: 19-36.

15. McCord JM (1998) Iron, free radicals, and oxidative injury. Semin Hematol 35: 5-12.

16. Daxenberger A, Ibarreta D, Meyer HH (2001) Possible health impact of animal oestrogens in food. Hum Reprod Update 7: 340-355.

17. Rose DP, Boyar AP, Wynder EL (1986) International comparisons of mortality rates for cancer of the breast, ovary, prostate, and colon, and per capita food consumption. Cancer 58 : 2363-2371.

18. Armstrong B, Doll R (1975) Environmental factors and cancer incidence and mortality in different countries, with special reference to dietary practices. Int J Cancer 15: 617-631.

19. World Cancer Research Fund, American Institute for Cancer Research Expert Panel (1997) Food, nutrition and the prevention of cancer: a global perspective. Washington (D. C.): American Institute for Cancer Research.

20. Scheppach W, Bingham S, Boutron-Ruault MC, Gerhardsson de Verdier M, et al. (1999) WHO consensus statement on the role of nutrition in colorectal cancer. Eur J Cancer Prev 8: 57-62.

21. United Kingdom Department of Health (1998) Nutritional aspects of the development of cancer. Norwich: Her Majesty's Stationery Office.

22. Larsson SC, Wolk A (2006) Meat consumption and risk of colorectal cancer: a meta-analysis of prospective studies. Int J Cancer 119: 26572664.

23. Norat T, Lukanova A, Ferrari P, Riboli E (2002) Meat consumption and colorectal cancer risk: dose-response meta-analysis of epidemiological studies. Int J Cancer 98: 241256.

24. Sandhu MS, White IR, McPherson K (2001) Systematic review of the prospective cohort studies on meat consumption and colorectal cancer risk: a meta-analytical approach. Cancer Epidemiol Biomarkers Prev 10: 439-446.

25. Larsson SC, Orsini N, Wolk A (2006) Processed meat consumption and stomach cancer risk: a meta-analysis. J Natl Cancer Inst 98: 1078-1087.

26. Steinmaus CM, Nunez S, Smith AH (2000) Diet and bladder cancer: a meta-analysis of six dietary variables. Am J Epidemiol 151: 693-702.

27. Michaud DS, Holick CN, Giovannucci E, Stampfer MJ (2006) Meat intake and bladder cancer risk in 2 prospective cohort studies. Am J Clin Nutr 84: 1177-1183.

28. Missmer SA, Smith-Warner SA, Spiegelman D, Yaun SS, Adami HO, et al. (2002) Meat and dairy food consumption and breast cancer: a pooled analysis of cohort studies. Int $\mathrm{J}$ Epidemiol 31: 78-85.

29. Cho E, Chen WY, Hunter DJ, Stampfer MJ, Colditz GA, et al. (2006) Red meat intake and risk of breast cancer among premenopausal women. Arch Intern Med 166: 2253-2259.

30. Bandera EV, Kushi LH, Moore DF, Gifkins DM, McCullough ML (2007) Consumption of animal foods and endometrial cancer risk: a systematic literature review and meta-analysis. Cancer Causes Control 18: 967-988.

31. Huncharek M, Kupelnick B, Wheeler L (2003) Dietary cured meat and the risk of adult glioma: a meta-analysis of nine observational studies. J Environ Pathol Toxicol Oncol 22: 129-137.

32. Larsson SC, Hakanson N, Permert J, Wolk A (2006) Meat, fish, poultry and egg consumption in relation to risk of pancreatic cancer: a prospective study. Int J Cancer 118: 2866-2870.

33. Lin Y, Kikuchi S, Tamakoshi A, Yagyu K, Obata Y, et al. (2006) Dietary habits and pancreatic cancer risk in a cohort of middle-aged and elderly Japanese. Nutr Cancer 56: 40-49.

34. Nothlings U, Wilkens LR, Murphy SP, Hankin JH, Henderson BE, et al. (2005) Meat and fat intake as risk factors for pancreatic cancer: the multiethnic cohort study. J Natl Cancer Inst 97: 1458-1465.

35. Dagnelie PC, Schuurman AG, Goldbohm RA, Van den Brandt PA (2004) Diet, anthropometric measures and prostate cancer risk: a review of prospective cohort and intervention studies. BJU Int 93: 1139-1150.

36. Faramawi MF, Johnson E, Fry MW, Sall M, Zhou Y (2007) Consumption of different types of meat and the risk of renal cancer: meta- 
analysis of case-control studies. Cancer Causes Control 18: 125-133.

37. Alavanja MC, Field RW, Sinha R, Brus CP, Shavers VL, et al. (2001) Lung cancer risk and red meat consumption among Iowa women. Lung Cancer 34: 37-46.

38. Sinha R, Kulldorff M, Curtin J, Brown CC, Alavanja MC, et al. (1998) Fried, well-done red meat and risk of lung cancer in women (United States). Cancer Causes Control 9: 621-630.

39. Gonzalez CA, Jakszyn P, Pera G, Agudo A, Bingham S, et al. (2006) Meat intake and risk of stomach and esophageal adenocarcinoma within the European Prospective Investigation Into Cancer and Nutrition (EPIC). J Natl Cancer Inst 98: 345-354.

40. Levi F, Pasche C, Lucchini F, Bosetti C, La Vecchia C (2004) Processed meat and the risk of selected digestive tract and laryngeal neoplasms in Switzerland. Ann Oncol 15: 346-349.

41. Tavani A, La Vecchia C, Gallus S, Lagiou P, Trichopoulos D, et al. (2000) Red meat intake and cancer risk: a study in Italy. Int J Cancer 86: 425-428.

42. Kushi LH, Mink PJ, Folsom AR, Anderson KE, Zheng W, et al. (1999) Prospective study of diet and ovarian cancer. American Journal of Epidemiology 149: 21-31.

43. Bertone ER, Rosner BA, Hunter DJ, Stampfer MJ, Speizer FE, et al. (2002) Dietary fat intake and ovarian cancer in a cohort of US women. Am J Epidemiol 156: 22-31.

44. Larsson SC, Wolk A (2005) No association of meat, fish, and egg consumption with ovarian cancer risk. Cancer Epidemiol Biomarkers Prev 14: 1024-1025.

45. Ziegler RG, Brinton LA, Hamman RF, Lehman HF, Levine RS, et al. (1990) Diet and the risk of invasive cervical cancer among white women in the United States. Am J Epidemiol 132: 432-445.

46. Cross AJ, Leitzmann MF, Gail MH, Hollenbeck AR, Schatzkin A, et al. (2007) A prospective study of red and processed meat intake in relation to cancer risk. PLoS Med 4: e325. doi:10.1371/journal.pmed.0040325

47. Deneo-Pellegrini H, De Stefani E, Ronco A, Mendilaharsu M, Carzoglio JC (1996) Meat consumption and risk of lung cancer; a casecontrol study from Uruguay. Lung Cancer 14: 195-205.

48. Castellsague X, Munoz N, De Stefani E, Victora CG, Castelletto R, et al. (2000) Influence of mate drinking, hot beverages and diet on esophageal cancer risk in South America. Int J Cancer 88: 658-664.

49. Ward MH, Sinha R, Heineman EF, Rothman N, Markin R, et al. (1997) Risk of adenocarcinoma of the stomach and esophagus with meat cooking method and doneness preference. Int J Cancer 71: 14-19.

50. Takezaki T, Gao CM, Wu JZ, Ding JH, Liu YT, et al. (2001) Dietary protective and risk factors for esophageal and stomach cancers in a lowepidemic area for stomach cancer in Jiangsu Province, China: comparison with those in a high-epidemic area. Jpn J Cancer Res 92: 11571165 .

51. Bahmanyar S, Ye W (2006) Dietary pattern and risk of squamous-cell carcinoma and adenocarcinoma of the esophagus and adenocarcinoma of the gastric cardia: population-based case-control study in Sweden. Nutr Cancer 54: 171-178.

52. Anderson KE, Sinha R, Kulldorff M, Gross M, Lang NP, et al. (2002) Meat intake and cooking techniques: associations with pancreatic cancer. Mutat Res 506-507; 225-231.

53. De Stefani E, Munoz N, Esteve J, Vasallo A, Victora CG, et al. (1990) Mate drinking, alcohol, tobacco, diet, and esophageal cancer in Uruguay. Cancer Res 50: 426-431.

54. Castelletto R, Castellsague X, Munoz N, Iscovich J, Chopita N, et al. (1994) Alcohol, tobacco, diet, mate drinking, and esophageal cancer in Argentina. Cancer Epidemiol Biomarkers Prev 3: 557-564.

55. Launoy G, Milan C, Day NE, Pienkowski MP, Gignoux M, et al. (1998) Diet and squamouscell cancer of the oesophagus: a French multicentre case-control study. Int J Cancer 76: 7-12.

56. Levi F, Pasche C, Lucchini F, Bosetti C, Franceschi S, et al. (2000) Food groups and oesophageal cancer risk in Vaud, Switzerland. Eur J Cancer Prev 9: 257-263.

57. Lyon JL, Slattery ML, Mahoney AW, Robison LM (1993) Dietary intake as a risk factor for cancer of the exocrine pancreas. Cancer Epidemiol Biomarkers Prev 2: 513-518.

58. Michaud DS, Giovannucci E, Willett WC, Colditz GA, Fuchs CS (2003) Dietary meat, dairy products, fat, and cholesterol and pancreatic cancer risk in a prospective study. Am J Epidemiol 157: 1115-1125.
59. Thompson FE, Midthune D, Subar AF, Kipnis V, Kahle LL, et al. (2007) Development and evaluation of a short instrument to estimate usual dietary intake of percentage energy from fat. J Am Diet Assoc 107: 760-767.

60. Hu FB (2002) Dietary pattern analysis: a new direction in nutritional epidemiology. Curr Opin Lipidol 13: 3-9.

61. Ledikwe JH, Blanck HM, Kettel Khan L, Serdula MK, Seymour JD, et al. (2006) Dietary energy density is associated with energy intake and weight status in US adults. Am J Clin Nutr 83: 1362-1368.

62. Ledikwe JH, Blanck HM, Khan LK, Serdula MK, Seymour JD, et al. (2006) Low-energydensity diets are associated with high diet quality in adults in the United States. J Am Diet Assoc 106: 1172-1180.

63. Newby PK, Muller D, Hallfrisch J, Qiao N, Andres R, et al. (2003) Dietary patterns and changes in body mass index and waist circumference in adults. Am J Clin Nutr 77: 1417-1425.

64. Matthews KH, Bernstein JJCB (2003) International trade of meat/poultry products and food safety issues. In: Buzby JC, editor. International trade and food safety: economic theory and case studies. Available: http://www. ers.usda.gov/Publications/AER828/. Accessed 12 November 2007.

65. European Commission Health and Consumer Protection Directorate General (2002) Opinion of the Scientific Committee on Veterinary Measures Relating to Public Health on Review of previous SCVPH opinions of 30 April 1999 and 3 May 2000 on the potential risks to human health from hormones residues in bovine meat and meat products. Available: http://ec.europa.eu/food/fs/sc/ scv/outcome_en.html. Accessed 12 November 2007.

66. United States Department of Health and Human Services and the Department of Agriculture (2005) Dietary Guidelines for Americans, 2005. Available: http://www.health. gov/dietaryguidelines/dga2005/document/ default.htm. Accessed 12 November 2007.

67. American Cancer Society (2005) Cancer Facts and Figures 2005. Available: http://www. cancer.org/docroot/STT/content/STT_1x Cancer_Facts_Figures_2005.asp. Accessed 12 November 2007 